\title{
Application of central-place foraging theory shows the importance of Mediterranean dehesas for the conservation of the cinereous vulture, Aegypius monachus
}

\author{
Martina Carrete ${ }^{a}$, José A. Donázar \\ Department of Applied Biology, Estación Biológica de Doñana (CSIC), Pabellón del Perú, Avda. María Luisa s/n, 41013 Sevilla, Spain
}

\begin{abstract}
The dehesa (oak woodland) is an extensive agro-pastoral ecosystem characteristic of the Western Mediterranean countries which is suVering a great transformation process since 1950. Although its distribution largely overlaps with several endangered species, there is scarce information on how they use this human-transformed habitat. We studied the foraging habitat selection of one of them, the cinereous vulture Aegypius monachus. We radio-tracked 14 cinereous vultures in one of the largest European colonies from 1998 to 2000. Used and available habitats were compared at two scales using compositional analysis. Moreover, we developed a distance-based GLMM for assessing habitat selection in this central-place forager species, by taking into account the spatial distribution of habitat patches in relation to the location of the colony. Home ranges overlapped over a total surface of 592,527 ha around the colony, and both individual home ranges and travel foraging distances (mean $27.86 \mathrm{~km}$, maximum $86 \mathrm{~km}$ ) were larger during the breeding season. All cinereous vultures avoided agricultural lands within their home ranges throughout the year. Habitat use in relation to the distance to the colony pointed out that dehesas were positively selected in spite of being on average far away from the colony than other habitats, a result that was consistent among individuals and seasons. The cinereous vulture thus depends for its conservation not only on the protection of breeding areas, as has been so far considered, but also on the maintenance of well-conserved dehesas close to the colonies. Preserving the cinereous vultures could contribute to the economic sustainability of dehesas by attracting PAC funds for their traditional low-intensity exploitation. Although other species may also beneWt from this study since cinereous vulture could be a "Xagship” for the large-scale conservation of Mediterranean oak woodlands and associated biodiversity, more Wne local management guidelines should be performed on the basis of studies on more sensitive species.
\end{abstract}

Keywords: Central-place forager; Cinereous vulture; European Common Agricultural Policy; Large-scale conservation; Spain

\section{Introduction}

European Mediterranean landscapes have been largely transformed by human activities over the last 10,000 years (Le Honerou, 1981). Agriculture development, grazing, silvicultural practices and natural and human-induced disturbances such as Wres have been the

\footnotetext{
* Corresponding author. Tel.: +34 9542323 40; fax: +34 9546211 25.

E-mail address: martina@ebd.csic.es (M. Carrete).
}

rule in most of the Mediterranean basin and, although such changes have reduced the extent of the primary biotopes, in many cases they have created new semi-natural habitats from which many animal species became dependent (e.g., Bignal and McCracken, 1996; Beaufoy, 1998; Díaz et al., 2003). Oak woodlands, for example, are mainly found in the Iberian Peninsula (but see Standiford et al., 2003 for more details on their worldwide distribution). Locally called dehesas (Spain) or "montados" (Portugal), this habitat type was a wood mainly composed by Quercus species which has been 

transformed into a savanna-like habitat, with scattered trees reaching densities of $40-50$ trees/ha, because of their use for livestock. The soil, sometimes occupied by small agriculture Welds, is generally covered by herbaceous plants which are proWted by sheep and cows while tree acorn production is usually consumed by the economically appreciated hairless black pigs.

The dehesas cover almost 3,000,000 ha of south-western Spain and Portugal (JoVre and Rambal, 1993). Its value for the conservation of the biodiversity has been repeatedly remarked. Besides holding a high diversity of plants (Pineda et al., 1981; Ruiz, 1986), its faunal richness is also considerable. As was stated by the reviews of Beaufoy (1998) and Díaz et al. (2003), dehesas and spatially related habitats as scrublands and woodlands maintain the main Western Palearctic and, in some cases, world populations of species considered as globally threatened or near-threatened such as the Spanish Imperial eagle Aquila adalberti, the cinereous vulture Aegypius monachus and the Iberian Lynx Lynx pardina (The 2004 IUCN Red List of the Threatened Species; information available at http://www.redlist.org/). These species, and many other predator vertebrates (see Beaufoy, 1998), prey mainly on wild rabbits Oryctolagus cuniculus whose densities in these habitats reach up to 15 individuals/ha (I. Fajardo, pers. com.). In addition, avian scavengers such as vultures and kites Milvus spp. rely on the carcasses of livestock (sheep, goats and cattle) maintained in these extensive exploitations. Wintering birds such as common cranes Grus grus, wood pigeons Columba palumbus or many passerine species use oak acorns as food source to increase their fat reserves (e.g., Herrera, 1977; Díaz et al., 1996, 1997). In spring, when the annual peak in number and biomass of arthropods occurs (Herrera, 1980), the bird community of the dehesas includes many near-threatened or vulnerable insectivorous species (e.g., shrikes Lanius meridionalis, L. senator, rollers Coracias garrulus) and top predators (e.g., black-shouldered kite Elanus caeruleus, booted eagle Hieraaetus pennatus, scops Otus scops and tawny owls Strix aluco Díaz et al., 1997).

Unfortunately, and except for some studies carried out in protected zones with relatively well-conserved original habitats as those found in the Doñana National Park and surrounding lands (see e.g., Heredia et al., 1991; Revilla et al., 2000), there is scarce information about the actual use that populations of endangered species, mainly raptors, make of dehesas and other related human-transformed Mediterranean habitats. This is of special interest when considering that large predators and scavengers usually travel long distances during their foraging trips, going outside the boundaries of protected areas and potentially exploiting patches with diVerent degrees of transformation. Thus, a better understanding of the use of man-made landscapes by these species would be essential for management and conservation purposes. Moreover, considering that since the 1950s dehesas are suVering conversion to monocultures of eucalyptus species and exotic pines (mainly until 1980s), overgrazing, abandonment of tree management, tree regeneration failures and conversion to irrigated land (Díaz et al., 1997; Pulido et al., 2001), this information could be useful to delineate future European compensation measures based on an optimal habitat design for the conservation of endangered taxa.

The cinereous vulture could be considered a representative species of this habitat type because its largest European breeding distribution, located in Spain (see below), largely overlaps with the distribution of dehesas (Fig. 1). Listed as globally near-threatened (IUCN, 2003; http:// www.redlist.org/) and considered as rare in Europe (BirdLife International, 2004) and vulnerable in Spain (Sánchez-Artés, 2004), the breeding population of this large scavenger showed a sharply decline through the XIXXXth centuries, reaching extinction in most of its former range (see Cramp and Simmons, 1980). In 2000, and after a recovering period, European breeding numbers were estimated in 1435-1977 pairs, of which 1203-1295 (approx. 70-80\%) occur in Spain (Donázar, 2002). There, it is known that local populations are aVected, among other factors, by illegal poisoning and disturbances in breeding areas (see Donázar et al., 2002) although no information exists about how they use the diVerent human-altered habitats that commonly found during their foraging activities. In fact, it should be noted that national and international conservation measures for this tree-nesting species are addressed to protect breeding colaonies but nothing is mentioned about the importance

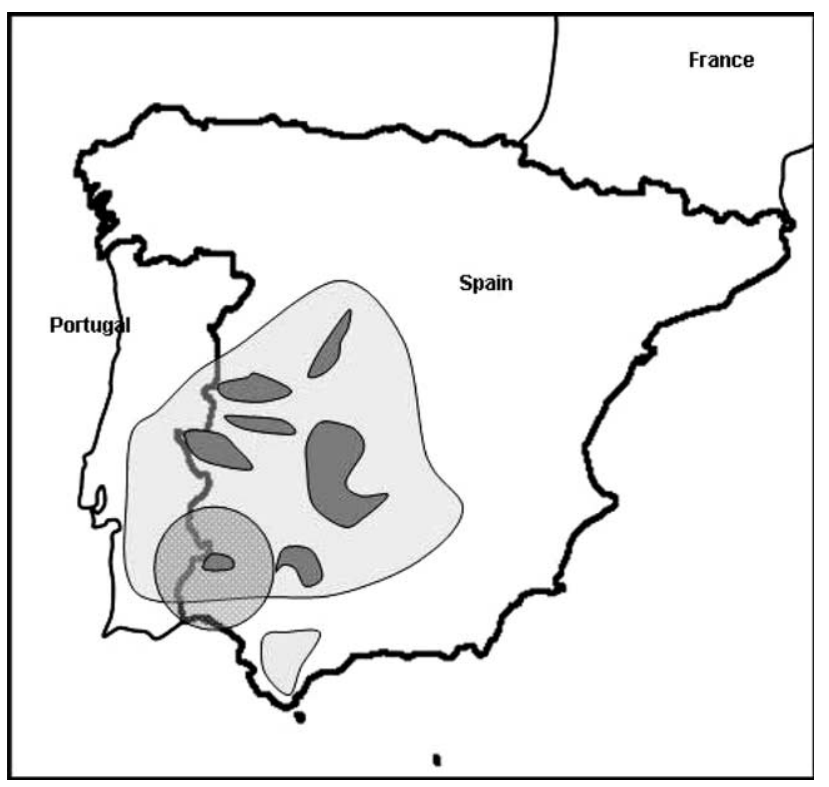

Fig. 1. Distribution of the dehesas (light grey; Standiford et al., 2004) and the breeding cores of cinereous vultures (dark grey; Martí and del Moral, 2003) in the Iberian Peninsula. The circle shows the study area. 
of maintaining its foraging habitats (Sánchez-Artés, 2004; Poirazidis et al., 2004). Contrarily, actions proposed are linked with the creation of "vulture restaurants” for artiWcial food supply (Sánchez-Artés, 2004) without a clear understanding of its role in the conservation of the species (but see Vlachos et al., 1999).

The aim of this paper was to examine the foraging habitat selection pattern of cinereous vultures breeding in the largest colony of Southern Spain in relation to the spatial distribution of dehesas. The species, which is at the "top" of the food web as consumer of carcasses of livestock and wild animals, may search through enormous land surfaces (see e.g., Mundy et al., 1992; Donázar, 1993) because of its large body-size and energetic requirements and the spatio-temporal unpredictability of its food resources. However, breeding birds are tied to the colony year-round (Donázar, 1993), behaving as central-place foragers (Orians and Pearson, 1979) which are obliged to return every day to their nest or roost-site at the colony. Hence, its foraging habitat selection pattern would be the result of a trade-oV between the quality of the diVerent patches (food-rich and food-poor habitats) and the distance at which they are located (low and high Xight cost;). Information about this subject may be critical for a good design of conservation strategies for this vulnerable raptor as well as for traditional agro-grazing systems in broad regions of the Iberian Peninsula.

\section{Study area}

Sierra Pelada is located at the western end of the Sierra Morena range, south-western Spain (37'51'10"N, $7^{\circ} 03^{\prime} 30^{\prime \prime} \mathrm{W}$ ), occupying around 40,000 ha of low mountains that range up to an altitude of 613 m.a.s.l. Annual rainfall is around $1000 \mathrm{~mm}^{3}$ and mean temperature is $15^{\circ} \mathrm{C}$. Although the natural vegetation was Mediterranean forest of evergreen, holm, and cork oaks (Quercusilex and Q. suber) with small patches of other tree species such as black alders Alnus glutinosa and strawberry trees Arbutus unedo, the area was deforested in the past for grazing activities, resulting in an open landscape dominated by Mediterranean scrubland with scattered woodland patches and isolated trees. In the 1960s and 1970s, the area underwent extensive transformation, with more than $70 \%$ of the land being reforested with eucalyptus trees (Eucalyptus spp.) and non-native pines (Pinus pinaster and Pinus pinea). In 1989, 13,000 ha were declared as "natural area" with the main aim of conserving the cinereous vulture breeding colony located in this already degraded place. Currently, in 2,323,527.36 ha around the breeding colony (our study area, see below), the dominant land-uses are crops (33\%, mainly extensive croplands), dehesas (23\%), open lands (19\%, mainly grasslands and shrublands) and exotic forest ( $17 \%$ and $3 \%$, for eucalyptus and pines, respectively).
The cinereous vulture breeding colony has increased from 45 pairs in the early 1970s (Hiraldo, 1974) to 90-100 pairs in 1993 (Andalus, 1996; authors' unpublished), decreasing to 72 pairs in 1998 (authors' unpublished). Causes of decline have been mainly attributed to illegal poisoning and disturbances in breeding areas (see Donázar et al., 2002).

\section{Methods}

\subsection{Field procedures}

During the winters of 1997, 1998 and 1999, we equipped with battery-operated transmitters (battery life: 2 years; Ayama, Biotrack and Wagner) 14 cinereous vultures (6 in 1997, 3 in 1998 and 5 in 1999) breeding in the Sierra Pelada colony. Birds were captured with rocket nets close to the breeding colony, by baiting them with carrions of livestock. Each vulture (10 males and 4 females, sexed though molecular procedures) was radiotracked an average of 44 days (range: 10-104 days) from March 1998 to June 2000, investing a total of 321 Weldwork days. We used two radio-tracking teams. The Wrst one was located, in alternative surveys, in a high point at the north or at the south of the breeding colony. The second team moved by car, intensively searching for birds in a radius of up to $100 \mathrm{~km}$ around the other team. Each team recorded the exact hour and the direction of each radio-location to triangulate vulture positions. Triangulation was performed with the programme LOAS (available at http://www.ecostats.com/index.htm). As locations obtained by biangulations are subject to biases when the resulting angle diVers from $90^{\circ}$ (White and Garrot, 1990), we were conservative selecting radiolocations and thus we considered only those that corresponded to foraging birds, obtained with two radio-locations within a period of $10 \mathrm{~min}$ and included within the range of $30-150^{\circ}$. Thus, we discarded approximately $40 \%$ of radiolocation data and the resulting dataset for analyses comprised 711 used points.

\subsection{Data analysis}

\subsubsection{Home range and habitat selection}

Home range size was obtained with the RANGES V package (Kenward and Hodder, 1996), using the 95\% Wxed kernel estimator (Worton, 1989, 1995). When it was possible (number of radiolocations 710 ; see below), we calculated the home ranges of adult birds for both, the breeding (February-July) and the non-breeding (August-January) season.

Using the compositional analysis proposed by Aebischer et al. (1993), we compared utilized and available habitats at two scales: (1) home range selection within the overall study area and (2) habitat selection within 
the home range. For the Wrst case, we considered that the study area was a circle of $86 \mathrm{~km}$ of radius (the maximum travel distance recorded during the study period; see results) centred in the vulture colony. For the second one, we used the 95\% Wxed kernel probability as an estimator of the home range of each individual. The compositional analysis, whose main advantage is to avoid biases due to the non-independence of proportions in habitat use, ranks habitats according to their relative use. After obtaining the diVerence d between the log-ratios of availability and use of each habitat, and taking the data matrix of $d$ values for each individual and habitat as a basis, it calculates the relation $h$ between the determinant of the matrix of mean-corrected sums of squares and cross-products (hypothesis tested: diVerential habitat use) and the determinant of the matrix of raw sums of squares and cross products (hypothesis tested: identical habitat use). The signiWcance of $h$ is then tested by means of the expression i $\mathrm{N} \ln h$, where $\mathrm{N}$ is the number of animals radiotracked, which follows a chi-square distribution. To determine where the diVerences lie in habitat use and to order the habitats according to their use for every individual, a table of relative use of each habitat is constructed, calculating for each comparison between habitats the proportion in which it is used with respect to the available proportion. Finally, habitat preference in each habitat comparison is compared with a random distribution provided by a computer program (J.F. Calvo, unpublished).

The use of a habitat patch by a central-place forager such as the cinereous vulture, that returns to the colony through the year for breeding and/or roosting, could be aVected by both the habitat's quality and proximity to the central place (see e.g., Rosenberg and McKelvey, 1999; Peach et al., 2004; Franco and Sutherland, 2004). Thus, we complementarily developed Generalized Linear Mixed Models (link function: logistic, error distribution: binomial; McCullagh and Searle, 2000) to describe mathematically the probability that a certain point within the study area was used by birds. The dataset included radiolocations of individuals (value 1) and an equal number of randomly selected points not used (value 0) but included within the study area (see above). Random points were obtained as independent x,y random coordinates within a uniformly sampled circular plot.

Circular plots of $2 \mathrm{~km}$ of diameter around each radiolocation and random point were used to extract habitat features, considering that this could be the area that a vulture could be prospecting when it was located (Donázar, 1993). We used a forward stepwise procedure to build models in which only signiWcant eVects were retained (Donázar et al., 1993). There, the proportion of each habitat was Wrst tested separately, by considering its linear and quadratic forms and including simulta- neously the distance of each point to the colony (distance) and the interaction between habitat and distance to the colony (habitat $\mathrm{X}$ distance). By this way, we can test not only for habitat preferences but also for potential constraints imposed by heterogeneity in spatial habitat distribution (Mysterud and Ims, 1998). After selecting the most important habitat type, we tried to incorporate the others, as well as their distances to the colony and the corresponding interactions to build multivariable models. In the construction of models, "individual" was always included as a random factor to control for the potential non-independence of data as well as to test for possible inter-individual diVerences in habitat selection, while "sex" (male and female) and "season" (breeding and non-breeding season) were considered as Wxed eVects (Serrano et al., 2001). A model was signiWcant if the probability associated with its coeYcients was lower than 0.05. For each signiWcant model, we calculated the percentage of deviance explained $\left(100 \propto\right.$ (100 i deviance model $\left._{\text {i }}\right) /$ deviance $\left._{\text {null model }}\right)$.

\subsubsection{Habitat types}

The percentages of the diVerent habitat types for the compositional analysis as well as for the radiolocations and the random points were obtained from the CORINE Land Cover database (CEC, 1991) by using the XTools extension (available at http://www.odf.state. or.us/stateforests/sfgis) of ArcView GIS 3.2. Although this general-purpose land-cover map of Europe has a relatively coarse resolution $(100 \mathrm{~m})$, it has been proved to be good enough to build broad habitat models of bird distribution (Seoane et al., 2004). Habitats were grouped in 4 categories that cover together more than $95 \%$ of the study area: exotic forest of eucalyptus trees (Eucalyptus spp.) and non-native pines such as $\mathrm{P}$. pinaster and P. pinea (hereafter, exotic forest), dehesas, agriculture lands and open areas such as grasslands and scrublands. Other habitats unsuitable for this species such as urban areas or seacoast and open sea were not considered in the analysis.

\section{Results}

\subsection{Home range}

The overall home range of the colony, estimated as a minimum by overlapping the home ranges of the 14 cinereous vultures radio-tracked, reached 592,527 ha. Each one of the individual home ranges mainly included open areas (28-31\%), dehesas (25-30\%) and exotic forest (21$29 \%)$. There were no changes in their relative habitat composition through the year (p-range D 0.076-0.397) in spite of their size contraction during the non-breeding season (breeding season: 135,430 § 61,191 ha, n D 14, and non-breeding season: 77,775 § 38,365 ha, n D 6; Mann- 
Table 1

Home ranges of cinereous vultures during the breeding (FebruaryJuly) and non-breeding (August-January) season in south-western Spain

\begin{tabular}{llllllr}
\hline IND & SEX & \multicolumn{2}{l}{ Breeding season } & & \multicolumn{2}{l}{ Non-breeding season } \\
\cline { 5 - 6 } & & $\begin{array}{l}\text { No. of } \\
\text { locations }\end{array}$ & Home range (ha) & $\begin{array}{l}\text { No. of } \\
\text { locations }\end{array}$ & Home range (ha) \\
\hline 102 & M & 25 & $126,706.1^{\text {a }}$ & & 23 & $25,482.10$ \\
103 & F & 71 & $133,197.2^{\text {a }}$ & & 16 & $89,771.44$ \\
104 & M & 49 & $288,670.9^{\text {a }}$ & & 56 & $104,413.60$ \\
105 & M & 43 & $162,442.2^{\text {a }}$ & & \\
106 & M & 51 & $127,512.5^{\text {a }}$ & & 23 & $38,215.06$ \\
107 & M & 61 & $238,816.1^{\text {a }}$ & & 20 & $124,259.70$ \\
109 & M & 76 & $109,699.4^{\text {a }}$ & 25 & $84,507.05$ \\
110 & M & 17 & $130,269.7$ & & \\
111 & F & 25 & $116,260.4$ & & \\
112 & F & 10 & $57,700.69$ & & \\
113 & M & 22 & $76,145.4$ & & \\
114 & M & 20 & $83,736.18$ & & \\
115 & F & 21 & $120,357.3$ & & \\
117 & M & 19 & $124,506.3$ & & \\
\hline
\end{tabular}

a Home ranges with stabilized area (for more details, see text).

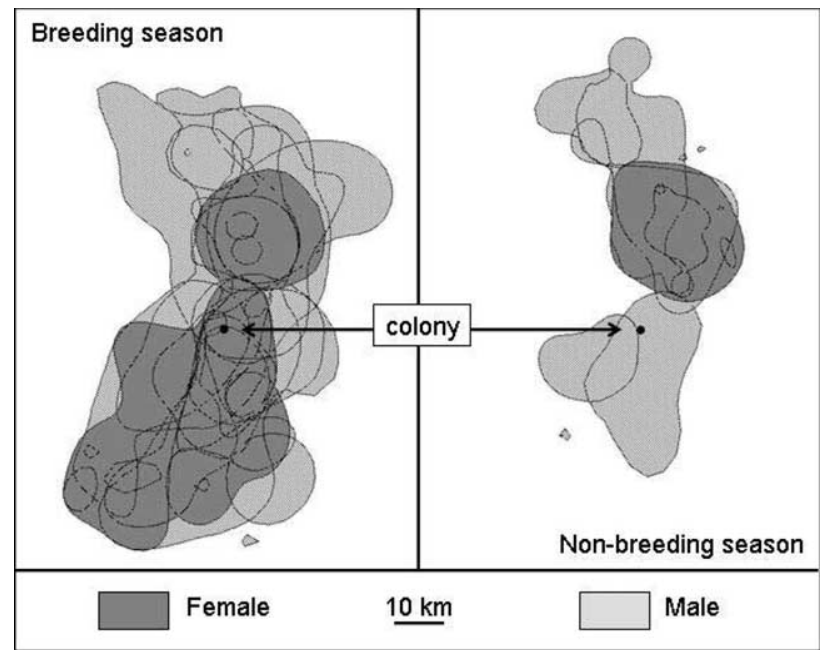

Fig. 2. Home ranges of male (M) and female (F) cinereous vultures during the breeding and the non-breeding seasons. Sample sizes: Breeding season: M D 10, F D 4; non-breeding season: M D 5, F D 1.

Whitney U-test D 15, p D 0.026), when travel distances were shorter (breeding season median: $27.86 \mathrm{~km}, \mathrm{nD} 14$, and non-breeding season median: $24.61 \mathrm{~km}, \mathrm{n} \mathrm{D} \mathrm{6}$; Mann-Whitney U-test D 40,090, p D 0.002). Males and females showed similar proportions of each habitat type within their home ranges (p-range D 0.374-0.945), which were also similar in size (males: 123,025 § 68,110 ha, n D 10, and females: 103,457 § 30,062 ha, n D 4; MannWhitney U-test D 33, pD 0.694) even during the breeding season (males: 146,851 § 67,273 ha, nD 10, and females: 106,879 § 33,570 ha, n D 4; Mann-Whitney U-test D 13, p D 0.322). We can assume that these home range sizes were reasonably estimated with the available sample size (see Table 1 and Fig. 2) because the number of locations for each bird and their home range sizes were not related (breeding season: r D 0.47, p D 0.094; non-breeding season: r D 0.24, p D 0.645).

\subsection{Habitat selection}

The compositional analysis indicated that the home ranges of cinereous vultures were not established at random within the study area during the breeding period ( $h$ D $9.34 £ 10^{i^{2}}, \quad z^{2}$ D 33.18, d.f. D 3, p $<0.0001$, n D 14 individuals). The ranking matrix (sequence of habitat types: open lands $>$ exotic forests $>$ dehesas $>$ agriculture lands) showed that agricultural lands were signiWcantly less used than any other habitat (p-range D 0.01570.0190 ), while there were not detectable diVerences in the intensity of use of the rest (p-range D 0.0938-0.4467). Within the home ranges, however, habitat use seemed always proportional to its availability ( $h \mathrm{D} 0.70$, $z^{2}$ D 4.97, d.f.D 3, p D 0.174, nD 14 individuals). Results

range vs. study area: $h \mathrm{D} 0.13, z^{2} \mathrm{D} 12.44$, d.f. D 3, p D 0.006, nD 6 individuals; agriculture lands less used than open areas: p D 0.047; the other habitat types were interchangeable: p-range D 0.0654-0.3715. Radiolocations vs. home range: $h \mathrm{D} 0.90, z^{2} \mathrm{D} 0.61$, d.f. $\mathrm{D} 3$, p D 0.893). To avoid potential biases associated with the number of radiolocations and be conWdent with our estimations of habitat selection, we plotted the percentage of increase in home range area as a result of increasing the number of locations for each individual to repeat analyses with those home ranges that showed a stabilized area. Although we substantially reduced our sample size to 7 individuals during the breeding season (Table 1), results remained unchanged (Home range vs. study area: $h \mathrm{D} 0.08, z^{2} \mathrm{D} 18.02$, d.f. D $3, \mathrm{p}<0.001$, n D 7 individuals; agriculture lands signiWcantly less used than any other habitat: p-range D 0.022-0.034; the other habitat types were interchangeable: p-range D 0.833-0.431; Radiolocations vs. home range: $h \mathrm{D} 0.61, z^{2} \mathrm{D} 3.43$, d.f. D 3, p D 0.33).

The above results, however, did not take into account the potential constraint that distance from the colony to diVerent habitat patches could impose on foraging vultures. Accordingly, a distance-based GLMM showed that the best regression model to predict habitat use only included the dehesas through its interaction with distance (Table 2). This result was consistent among individuals (Wtted as random term, p D 0.389) independently of their sex (p D 0.839) and of the season ( $\mathrm{p} \mathrm{D} \mathrm{0.354).} \mathrm{The}$ positive sign of this interaction pointed out that dehesas were positively selected by birds in spite of being far away from the colony. In this sense, and considering the dominant habitat at each radiolocation (coverage 750\%), the distance at which cinereous vulture used dehesas (median D $31.68 \mathrm{~km}$ ) was signiWcantly higher than the observed for the other habitat types 
Table 2

Generalized Linear Mixed Model obtained to predict the foraging habitat use of cinereous vultures (Aegypius monachus) in south-western Spain (1998-2000) in relation to distance to the colony

\begin{tabular}{lllrr}
\hline Parameter & Estimate & SE & F-test & \multicolumn{1}{c}{ P } \\
\hline Dehesas & $\mathbf{i}^{0.88}$ & 0.67 & 1.76 & 0.1853 \\
Dist & $\mathbf{i}^{8} £ 10^{\mathbf{i}^{5}}$ & $5.12 £ 10^{\mathbf{i}^{6}}$ & 254.28 & $<0.001$ \\
Dehesas $E$ dist & $3.8 £ 10^{\mathbf{i}^{5}}$ & $1.5 £ 10^{\mathbf{i}^{5}}$ & 6.35 & 0.0118 \\
\hline
\end{tabular}

The eVects individual (Wtted as random factor), season and sex (Wtted as Wxed eVects) did not reach signiWcance into the model (p range D 0.354-0.839). dehesas: coverage of dehesas in a radius of $2 \mathrm{~km}$, dist: linear distance to the breeding colony. Deviance explained by the model: $27.62 \%$.

Degrees of freedom: 1415.

(median D 23.44 km; $\quad$ Mann-Whitney U-test D 24,872, $\mathrm{p}<0.0001)$.

\section{Discussion}

Cinereous vultures included within their home ranges similar proportions of dehesas, open areas and exotic forest, avoiding the use of agricultural lands. However, choosing the proportion of habitat types within a home range as a null model of availability involves the implicit assumption that no factors other than habitat type aVect its use, which could not be always reasonable (Otis, 1997, 1998; Johst et al., 2001; Peach et al., 2004). The use of a habitat patch by individuals exhibiting central-place behaviour as the cinereous vulture may be due to both the habitat quality and the proximity to the central place (Franco and Sutherland, 2004). In this sense, when a distance-based model was performed, we Wnd that dehesas were actively selected compared with the other land uses in spite of being farther away from the colony. Thus, the similar preference for exotic forest, open areas and dehesas within the home ranges obtained with the compositional analysis may be a consequence of birds eventually prospecting these habitats while travelling from their nests to the dehesas. This is reinforced by our lack of observations of vultures feeding in exotic forests (author's unpublished data).

Foraging habitat selection in most animal species is commonly assumed to be inXuenced by the availability and/or accessibility of their main prey species (e.g., Newton, 1994; Widen, 1994; Tella et al., 1998; Palomares et al., 2001; Franco and Sutherland, 2004). Although data to accurately estimate food availability in our study area is not available, we can infer it through cattle statistics (cows, sheep, goats, and pigs; Spanish Institute of Statistics, 1999) and oYcial hunting reports of rabbits (I. Fajardo, unpublished data), which constitute the main food items of this species (Hiraldo, 1976). Assuming a positive relationship between these values and food availability for vultures (i.e., more cattle and more hunted rabbits should imply more carcases and rabbit corpses in the Weld), the above mentioned data suggest that dehesas could be an important foraging habitat for cinereous vulture because it maintains high relative abundances of rabbits at the same time that they are commonly used for livestock grazing. Contrarily to what happens in other regions, however, agricultural lands in the Andalusian study area are mainly free of grazing animals because they do not remain uncultivated through long periods of time (see e.g., Tella et al., 1998). Moreover, although they hold the highest rabbit abundances (I. Fajardo, unpublished), the presence of people working in the Weld as well as car traYc can discourage their use by cinereous vultures (Donázar et al., 2002; Bautista et al., 2004).

There were also some evidences for seasonal changes in home range. Contrary to what happens in other raptor species which are tied to a nesting place during the breeding season but then (i.e., during the non-breeding season) move through larger areas (MarzluV et al., 1996; Burton and Olsen, 2000; Dykstra et al., 2001; Sunde et al., 2001), home range of cinereous vultures were bigger during the breeding period. This could be because daylight time is shorter in winter, thus decreasing the number of hours available for Xight and, consequently, the surface prospected by cinereous vultures (Hiraldo and Donázar, 1990). Moreover, the higher food requirements associated with reproduction can force vultures to prospect across larger surfaces, looking for the unpredictable location of carrions to satisfy food provisioning for oVspring and themselves. Here, it should be noted that although the straight-line travel foraging distances previously estimated for this vulture through the eventual observations of Xying birds (around $30 \mathrm{~km}$, Mundy et al., 1992; Donázar, 1993) were markedly smaller than those obtained in this study by tracking birds, since more than $40 \%$ of our data correspond to larger distances (reaching up to $86 \mathrm{~km}$ ). This increase, likely resulting from biases in evaluating movements without radiotracking methods (since the probability of visually detecting birds decays at higher distances to the nest due to the area increase), might reinforce the selection of dehesas as foraging habitat, which in the study area are at a median distance of $50 \mathrm{~km}$ (range D 15-85 km). Moreover, as central-place foragers are expected to depress resources unevenly across their home range (Orians and Pearson, 1979), mainly in the case of colonial species (Fernández et al., 1998; Lewis et al., 2001; Forero et al., 2002) such as this vulture, foraging distances could increase in the future if conservation measures to maintain the traditional exploitation of dehesas as well as to restore the degraded areas are not taken into account. As was observed in other colonial species, increments in food-searching distances can have Wtness consequences in terms or reducing oVspring quantity and/or quality 
(Tella et al., 1998, 2001; Forero et al., 2002), even aVecting large-scale population trends (e.g., Tella et al., 1998).

\subsection{Management implications}

QuantiWcation of wildlife resource selection is critically important for impact assessment and management planning. The conservation of cinereous vulture, contrarily to many other species, has been primary focused on breeding cores (Donázar et al., 2002; Poirazidis et al., 2004) taking less attention to foraging habitat requirements, perhaps because nesting failures are obvious when they are related with direct disturbances but less apparent when they are linked to prey depression through habitat degradation or management away from nesting sites (Tella et al., 1998; Rodríguez, 2004). In this sense, our results point out that protecting "breeding islands" within severely transformed landscapes, as it is the case of our studied colony, is not useful enough for a large vertebrate such as the cinereous vulture that needs to prospected large surfaces for obtaining food resources. Breeding cinereous vultures require, apart from mature trees for nesting, the existence of adequate foraging habitat such as the dehesas in the neighbourhood which could not be easily replaced by the creation of supplementary food points (commonly called "vulture restaurants") supplied with just carcasses of large livestock. These feeding stations could have been beneWcial for the species in some regions (Vlachos et al., 1999), but in Spain they are scarcely used by cinereous vultures probably because they are overexploited by larger numbers of the commonest GriVon vulture Gyps fulvus (Authors, unpublished data). Although the large home range of cinereous vultures allow nesting and foraging habitats to be not so close, birds would beneWt from the maintenance and, if it is necessary as in the study area, restoration of these habitat types close around the colony because they would reduce the costs associated with long travel distances as those detected in our study (see above).

Changes in dehesas since the 1950s were strong and have included their conversion to exotic forests of eucalyptus and pines, as happened in the study area and in many other parts of the Iberian Peninsula (e.g., Algarve, in Portugal, or Monfragüe, in Spain, holding other of the larger cinereous vulture colony), local increases in livestock density, abandonment of tree management, tree regeneration failures, and conversion to irrigated land. Currently, lack of natural regeneration due to overgrazing by livestock or big game in some places, and abandonment in others, is the main conservation problem for the dehesas system (Pulido et al., 2001). These changes may have been detrimental for many other species besides of the cinereous vulture. A further conservation problem associated with changes in dehesas is their inclusion into intensive hunting areas where the illegal use of poison for predator control is usual. Rabbit diseases have lead to an increase in the number of poison- ing events in Spain (Villafuerte et al., 1998), resulting in a high raptor mortality (Cano, unpublished). In fact, for the cinereous vulture, adult mortality reaches $20 \%$ in the studied colony mainly due to poisoning of birds during foraging activities (Donázar et al., 2002).

Dehesas are included in the Annex. 1 of the EU Habitat Directive to be considered during the designation of Special Areas of Conservation within the Natura 2000 network. However, Natura 2000 is not intended to include all areas where a habitat type is present, but rather a selection of the most representative and bestconserved areas. Besides, dehesas are a biotope which has been created and need to be maintained by people, but it is needed to ensure that the intensity of management and exploitation is appropriated (Bignal and McCracken, 1996; Beaufoy, 1998; Plieninger and Wilbrand, 2001; Díaz et al., 2003). As management decisions on these lands are in private hands and determined primarily by the European Common Agricultural Policy, agri-environment payments for the traditional lowintensity exploitation of dehesas, taking into account nature conservation, could play a mayor role in their long-term permanence as well as in the conservation of the species that depend on them (Díaz et al., 1997). This payment to compensate commercial losses may encourage the maintenance of this traditional low intensity land use in large areas of Spain and Portugal.

Finally, we want to remark that, although the idea of carrying out conservation actions at large scales has long been recognized, the focus had tended to be on individual reserve size, connection between reserves and buVering of anthropogenic impacts on core conservation areas (e.g., Diamond, 1975; SimberloV, 1986; Hobbs, 1992; Groom et al., 1999). Cinereous vultures, as many other large vertebrates, require large home ranges for foraging activities, reXecting its potential "umbrella species" role for the conservation of dehesas. However, beyond the Wnding that this species requires large habitat extensions for persistence (the total colony home range is at least 592,000 ha) we did not test if this is an eVective umbrella species for Wne-scale management of dehesas (Roberge and Anglestam, 2004). Thus, we propose the use of this charismatic bird as a "Xagship" species for the largescale maintenance of dehesas while more Wne local management guidelines are performed on the basis of studies on smaller, maybe more sensitive species such as small mammals or birds, lizards and invertebrates (Pulido and Díaz, 1998; RubinoV, 2001; Martín and López, 2002; Roberge and Anglestam, 2004).

\section{Acknowledgements}

We thank M. de la Riva very much for his decisive and careful work at all stages of the research. J. Blas, J. Bustamante, M. Cabaco, J. Caballero, S. Cabezas, A. 
Fernández, V. Fiscal, M.G. Forero, L. Gangoso, G. García, H. Garrido, M. Gómez, J. M. Hornero, F. Ibáñez, L. Infante, E. Luque, I. Luque, J. Martín, F. Martínez, F. Molino, J.J, Negro, M. Pérez, M.A. Pineda, J. Rengel, M. Rico, G. de la Riva, R. Rodríguez, M. Ruiz, C. San Segundo, J.M. Sayago, A. Sierra, J.R. Súnico, and J.L. Tella helped with the Weld tasks. I. Fajardo provided data on rabbit abundance. J.F. Calvo and J.D. Anadón helped with the compositional analysis. J.L. Tella, J.A. SánchezZapata, F. Hiraldo, J.M. Grande, M. Díaz, and two anonymous referees made many constructive comments on the earlier versions of the manuscript. The study was Wnanced by the Consejería de Medio Ambiente, Junta de Andalucía. When writing up the paper, M.C. was supported by a postdoctoral grant from Fundación Séneca (Murcia, Spain).

\section{References}

Aebischer, N.J., Robertson, P.A., Kenward, R.E., 1993. Compositional analysis of habitat use from animal radio-tracking data. Ecology 74, 1313-1325.

Andalus, 1996. Buitre Negro. Boletín MonográWco no. 21, Huelva. Bautista, L.M., García, J.T., Calmaestra, M.G., Palacín, C., Martín, C.A., Morales, M.B., Bonal, R., Viñuela, J., 2004. EVect of weekend road traYc on the use of space by raptors. Conservation Biology $18,726-732$.

Beaufoy, G., 1998. The EU habitats directive in Spain: can it contribute eVectively to the conservation of extensive agro-ecosystems? Journal of Applied Ecology 35, 974-978.

Bignal, E.M., McCracken, D.I., 1996. Low-intensity farming system in the conservation of the countryside. Journal of Applied Ecology 33, $413-424$.

Bird Life International, 2004. Birds in Europe: population estimates, trends and conservation status. Available from: <http://www.birdlife.org/datazone/species/BirdsInEuropeII/BiE2004Sp3380.pdf >.

Burton, A.M., Olsen, P., 2000. Niche partitioning by two sympatric Goshawks in the Australian wet tropics: ranging behaviour. Emu 100, 216-226.

CEC, 1991., CORINE Land Cover, Commission of the European Communities: ECSC-EEC-EAEC, Brussels, Luxembourg.

Cramp, S., Simmons, K.E.L., 1980. The Birds of the Western Paleartic. Oxford University Press, Oxford.

Diamond, J.D., 1975. The island dilemma: lessons of modern biogeographic studies for the design of natural reserves. Biological Conservation 7, 129-146.

Díaz, M., González, E., Muñoz-Pulido, R., Naveso, M.A., 1996. Habitat selection patterns of common cranes Grus grus wintering in holm oak Quercus ilex dehesas of central Spain: eVects of human management. Biological Conservation 75, 119-123.

Díaz, M., Campos, P., Pulido, F.J., 1997. The Spanish dehesas: a diversity in land-use and wildlife. In: Pain, D.J., Pienkowski, M.W. (Eds.), Farming and Birds in Europe. The Common Agricultural Policy and its Implications for Bird Conservation. Academic Press, San Diego, pp. 178-209.

Díaz, M., Pulido, F.J., Marañón, T., 2003. Diversidad biológica y sostenibilidad ecológica y económica de los sistemas adehesados. Ecosistemas 2003/3. Available from: <http://www.aeet.org/ecosistemas/ 033/investigacion 4 .htm>.

Donázar, J.A., 1993. Los buitres ibéricos. Quercus, Madrid.

Donázar, J.A., 2002. Tendencias recientes de la población española de buitre negro: evaluación de factores limitantes y medidas de con- servación. Terceras Jornadas CientíWcas del Parque Natural de Peñalara y del Valle del Paular. Consejería de Medio Ambiente de la Comunidad Autónoma de Madrid, Madrid. pp. 81-87.

Donázar, J.A., Hiraldo, F., Bustamante, J., 1993. Factors inXuencing nest site selection, breeding density and breeding success in the bearded vulture (Gypaetus barbatus). Journal of Applied Ecology 30, 504-514.

Donázar, J.A., Blanco, G., Hiraldo, F., Soto-Largo, E., Oria, J., 2002. EVects of forestry and other land-use practices on the conservation of Cinereous Vultures. Ecological Applications 12, 14451456.

Dykstra, C.R., Hays, J.L., Daniel, F.B., Simon, M.M., 2001. Home range and habitat use of suburban red-shouldered Hawks in Southwestern Ohio. Wilson Bulletin 113, 308-316.

Fernández, C., Azcona, P., Donázar, J.A., 1998. Density-dependent eVects on productivity in the GriVon vulture Gyps fulvus: the role of interference and habitat heterogeneity. Ibis 140,64-69.

Forero, M.G., Tella, J.L., Hobson, K.A., Bertellotti, M., Blanco, G., 2002. ConspeciWc food competition explains variability in colony size: a test in magellanic penguins. Ecology 83, 3466-3475.

Franco, A.M.A., Sutherland, W.J., 2004. Modelling the foraging habitat selection of lesser kestrels: conservation implications of European Agricultural Policies. Biological Conservation 120, 63-74.

Groom, M., Jensen, D.B., Knight, R.L., Gatewood, S., Mills, L., BoydHeger, D., Mills, L.S., Soulè, M., 1999. BuVer zones: beneWts and dangers of compatible stewardship. In: Soulè, M.E., Terborgh, J. (Eds.), Continental Conservation: ScientiWc Foundations of Regional Reserve Networks. Island Press, Washington, pp. 171197.

Heredia, B., Alonso, J.C., Hiraldo, F., 1991. Space and habitat use by Red kites Milvus milvus during winter in the Guadalquivir marshes: a comparison between resident and wintering populations. Ibis 133, 374-381.

Herrera, C., 1977. Ecología alimenticia del petirrojo (Erithacus rubecula) durante su invernada en encinares del sur de España, Doñana. Acta Vertebrata 4, 35-39.

Herrera, C., 1980. Composición y estructura de dos comunidades de passeriformes. Doñana. Acta Vertebrata 7,1-340.

Hiraldo, F., 1974. Colonias de cría y censos de los buitres negros en España. Naturalia Hispanica no. 2. ICONA, Madrid.

Hiraldo, F., 1976. Diet of the Black vulture (Aegypius monachus) in the Iberian Peninsula, Doñana. Acta Vertebrata 3,19-31.

Hiraldo, F., Donázar, J.A., 1990. Foraging time in the Cinereous Vulture (Aegypius monachus): seasonal and local variations and inXuence of weather. Bird Study 37, 128-132.

Hobbs, R.J., 1992. Role of corridors in conservation: solution or bandwagon? Trends in Ecology and Evolution 7, 389-392.

IUCN, 2003. Red List of Threatened Species. Available from: <http:// www.redlist.org/>.

JoVre, R., Rambal, S., 1993. How tree cover inXuences the water balance of Mediterranean rangelands. Ecology 74, 570-582.

Johst, K., Brandl, R., Pfeifer, R., 2001. Foraging in a patchy and dynamic landscape: human land use and the White Stork. Ecological Applications 11, 60-69.

Kenward, R.E., Hodder, K.H., 1996. RANGES V: An Analysis System for Biological Location Data. Institute of Terrestrial Ecology, Wareham, Dorset.

Le Honerou, H.N., 1981. Impact of man and his animals on Mediterranean vegetation. In: di Castri, F., Goodall, D.W. (Eds.), Ecosystems of the World. Elsevier ScientiWc Publishing Company, Amsterdam, pp. 479-521.

Lewis, S., Sherratt, T.N., Hamer, K.C., Wanless, S., 2001. Evidence of intra-speciWc competition for food in a pelagic seabird. Nature 412 , 816-819.

Martí, R., del Moral, J.C., 2003. Atlas de las aves reproductores de España. Dirección General de Conservación de la NaturalezaSociedad Española de Ornitología, Madrid. 
Martín, J., López, P., 2002. The eVect of Mediterranean dehesa management on lizard distribution and conservation. Biological Conservation 108, 213-219.

MarzluV, J.M., Knick, S.T., Vekasy, M.S., Schueck, L.S., Zarriello, T.J., 1996. Spatial use and habitat selection of Golden Eagles in Southwestern Idaho. Auk 114, 673-687.

McCullagh, P., Searle, S.R., 2000. Generalized Linear and Mixed Models. Wiley-Interscience, New York.

Mundy, P., Butchart, D., Ledger, J., Piper, S., 1992. The Vultures of Africa. Academic Press, San Diego.

Mysterud, A., Ims, R.A., 1998. Functional responses in habitat use: availability inXuences relative use in trade-oV situations. Ecology 79, 1435-1441.

Newton, I., 1994. Experiments on the limitation of bird breeding densities: a review. Ibis 136, 397-411.

Orians, G.H., Pearson, N.E., 1979. On the theory of central place foraging. In: Horn, B.J., Stairs, G.R., Mitchell, R.D. (Eds.), Analysis of Ecological Systems. Ohio State University Press, Columbus, pp. 155-177.

Otis, D.L., 1997. Analysis of habitat selection studies with multiple patches within cover types. Journal of Wildlife Management 61, 1016-1022.

Otis, D.L., 1998. Analysis of the inXuence of spatial pattern in habitat selection studies. Journal of Agricultural, Biological and Environmental Statistics 3, 254-267.

Palomares, F., Delibes, M., Revilla, E., Calzada, J., Fedriani, J.M., 2001. Spatial ecology of Iberian lynx and abundance of European rabbits in southwestern Spain. Wildlife Monographs 148, 1-36.

Peach, W.J., Denny, M., Cotton, P.A., Hill, I.F., Gruar, D., Barritt, D., Impey, A., Mallord, J., 2004. Habitat selection by song thrushes in stable and declining farmland populations. Journal of Applied Ecology 41, 275-293.

Pineda, F.D., Nicolas, J.P., Ruiz, M., Peco, B., Bernáldez, F.G., 1981. Succession, diversité et amplitude de niche dans les pasturages du centre de la péninsule ibérique. Vegetatio 47, 267-277.

Plieninger, T., Wilbrand, C., 2001. Land use, biodiversity conservation, and rural development in the dehesas of Cuatro Lugares, Spain. Agroforestry Systems 51, 23-34.

Poirazidis, K., Goutner, V., Skartsi, T., Stamou, G., 2004. Modelling nesting habitat as a conservation tool for the Eurasian black vulture (Aegypius monachus) in Dadia Nature Reserve, northeastern Greece. Biological Conservation 118, 235-248.

Pulido, F.J., Díaz, M., 1998. Linking individual foraging behavior and population spatial distribution in patchy environments: a Weld example with Mediterranean blue tits. Oecologia 111, 434-442.

Pulido, F.J., Díaz, M., Hidalgo de Trucios, S.J., 2001. Size struture and regeneration of Spanish holm oak Quercus ilex forests and dehesas: eVects of agroforestry use on their long-term sustainability. Forest Ecology and Management 146, 1-13.

Revilla, E., Palomares, F., Delibes, M., 2000. DeWning key habitats for low density populations of Eurasian badgers in Mediterranean environments. Biological Conservation 95, 269-277.

Roberge, J.M., Anglestam, P., 2004. Usefulness of the umbrella species concept as a conservation tool. Conservation Biology 18, 76-85.

Rodríguez, C., 2004. Factores ambientales relacionados con el éxito reproductivo del cernícalo primilla, Cambio climático e intensiWcación agraria, PhD. Thesis. University of Salamanca, Salamanca.
Rosenberg, D.K., McKelvey, K.S., 1999. Estimation of habitat selection for central-place foraging animals. Journal of Wildlife Management 63, 1028-1038.

RubinoV, D., 2001. Evaluating the California gnatcatcher as an umbrella species for conservation of Southern California coastal sage scrub. Conservation Biology 15, 1374-1383.

Ruiz, M., 1986. Sustainable food and energy production on the Spanish dehesas. The Food Energy Nexus Programme no. 16. United Nations University, Paris.

Sánchez-Artés, J.J., 2004. Buitre Negro, Aegypius monachus. In: Madroño, A., González, C., Atienza, J.C. Libro Rojo de las aves de España, Dirección General de Conservación de la NaturalezaSEO/BirdLife, Madrid.

Seoane, J., Bustamante, J., Diaz-Delgado, R., 2004. Are existing vegetation maps adequate to predict bird distributions? Ecological Modelling 175, 137-149.

Serrano, D., Tella, J.L., Forero, M.G., Donázar, J.A., 2001. Factors aVecting breeding dispersal in the facultatively colonial lesser kestrel: individual experience vs. conspeciWc cues. Journal of Animal Ecology 70, 568-578.

SimberloV, D.S., 1986. Design of nature reserves. In: Usher, M.B. (Ed.), Wildlife Conservation and Evaluation. Chapman and Hall, London.

Standiford, R.B., Huntsinger, L., Campos, P., Martin, D., Mariscal, P., 2003. The bioeconomics of Mediterranean oak woodlands: issues in conservation policy. In: XII World Forestry Congress Proceedings, Quebec, Canada, pp. 111-120.

Sunde, P., Overskaug, K., Bolstad, J.P., Oien, I.J., 2001. Living at the limit: ecology and behaviour of Tawny Owls Strix aluco in a northern edge population in central Norway. Ardea 89, 495-508.

Tella, J.L., Forero, M.G., Hiraldo, F., Donázar, J.A., 1998. ConXicts between lesser kestrel conservation and European Agricultural Policies as identiWed by habitat use analysis. Conservation Biology 12, 593-604.

Tella, J.L., Forero, M.G., Bertellotti, M., Donázar, J.A., Blanco, G., Ceballos, O., 2001. OVspring body condition and immunocompetence are negatively aVected by high breeding densities in a colonial seabird: a multiscale approach. Proceedings Royal Society London B 268, 1455-1461.

Villafuerte, R., Vinuela, J., Blanco, J.C., 1998. Extensive predator persecution caused by population crash in a game species: the case of red kites and rabbits in Spain. Biological Conservation 84, 181-188.

Vlachos, C.G., Bakaloudis, D.E., Holloway, G.J., 1999. Population trends of Black vultures Aegypius monachus in Dadia Forest, north-eastern Greece following the establishment of a feeding station. Bird Conservation International 9, 113-188.

White, G.C., Garrot, R.A., 1990. Analysis of Wildlife Radio-Tracking Data. Academic Press, New York.

Widen, P., 1994. Habitat quality for raptors: a Weld experiment. Journal of Avian Biology 25, 219-223.

Worton, B.J., 1989. Kernel methods for estimating the utilization distribution in home-range studies. Ecology 70, 164-168.

Worton, B.J., 1995. Using Monte Carlo simulation to evaluate kernelbased home range estimators. Journal of Wildlife Management 59, 794-800. 